\title{
Biological Control Against Bayoud Disease of Date Palm (Phoenix dactylifera L.) using Antagonistic Fungi Species: Antibios and Mycoparasitism Studies
}

\author{
Ibrahim Elkhalil Benzohra' ${ }^{1}$, Mohamed Megateli \\ Station Expérimentale du Milieu Biophysique de la Saoura, Taghit, Béchar - Centre for Scientific and Technical Research on Arid Regions \\ (CRSTRA), Campus Universitaire B. P. 1682 RP, Biskra, Algeria.
}

\begin{abstract}
Fusarium wilt of date palm, also known as bayoud disease, is major disease in Algeria and Morocco. In this work, we studied a biological control of Fusarium oxysporum $f$. sp. albedinis, the causal agent of bayoud disease by using of an antagonistic fungi species (AFS), (Aspergillus niger, Fusarium oxysporum, Trichoderma harzianum, T. aureoviride and T. longibachiatum), for biological control test by antibiosis and mycoparasitism actions. We showed the antibiosis action by the inhibition of mycelial growth and sporulation inhibitions, and the mycoparasitism action by cytological alteration of Foa mycelia. All five antagonistic fungi showed significant effect $(P<0.05)$, of inhibition toward mycelial growth of Foa $(60-75 \%)$, and its sporulation (80-85\% of the control). The mycoparasitism action observed by AFS secretions of the anti-fungal lytic enzymes, chitinase and $\beta$-1,3-Glucanase, and also by microscopic observation showed clearly this action by coagulation and alteration of Foa mycelium and appearance of large vacuoles.
\end{abstract}

Keywords: date palm, Fusarium oxysporum f. sp. albedinis, bayoud, biocontrol, antibiosis, mycoparasitism.

\section{Introduction}

The Fusarium wilt of date palm (Phoenix dactylifera L.), commonly named bayoud, caused by the fungus Fusarium oxysporum f. sp. albedinis (Foa), is the most destructive disease of date palm. The impact of this disease is most severe in North Africa, where 10 million of palm trees were destroyed in Morocco, and 3 million in Algeria[1].This disease appeared for the first time in 1870 in the Draa valley in the south of Morocco[2].The spread of this disease in Morocco can be explained by the advancement from one oasis to another along the river valleys, for example, from Morocco, the Bayoud entered in Algeria via oases close to the borders in Moroccan frontiers like Figuig oasis, by Zouzfana and saoura valleys. From there the fungus travelled via the caravan-routes in infested wood and branch to the oases of central Algeria [3,4].

The fighting strategies against this disease are very limited. Among these strategies, the deployment of Foa-resistant cultivars appear to be the most suitable and economic approach5,6, but natural resistant genotypes are scarce with a poor quality of fruits and the date palm breeding system is laborious and offered only as a long-term plan7. Alternative control measures such as the use of Foa antagonists are, therefore, necessary and need to be explored8.

Biological control using microorganisms represents a promising disease control alternative9. This kind of control is based on the screening of plant extracts or antagonistic bacteria and fungi that can confer protection against plant pathogens [9-11]. Several biocontrol agents were identified, including species of Trichoderma, Penicillium, Gliocladium, Sporidesmium, Burkholderia, Bacillus, Serratia, and many others. However, their efficacy has been often inconsistent when transferred into the field. Improving the success of such transfer relies on the elucidation of the mechanism of action and of how such mechanisms are affected by the environment [12].

Biocontrol agents achieve a better disease control via a microbial antagonism, which implies a direct interaction with the causal agent of disease and/or an indirect action involving the host $[13,14]$. The direct effect is usually a result of an antagonism between the biocontrol agent and the pathogen due to antibiosis or nutrient competition and/or parasitism, whereas the indirect interaction results from the enhancement of the plant defense mechanisms against the invading pathogen[15-19]. Hammerschmidt and Kuc20 reported that induced resistance in plants was associated with the enhancement of the cell wall lignifications, the stimulation of host-defense enzymes and the synthesis of pathogenesis-related (PR) protein. Concerning date palmFoa interaction, El Hassni et al.11 reported that the inoculation of date palm seedlings with a hypoaggressive isolate of $F$. oxysporum provided a degree of protection against further attacks by an aggressive isolate of Foa. Jaiti et al. [21] tested the effect of root colonization with arbuscular mycorrhizal fungi, on the induction of date palm defense reactions against its pathogen. ElHadrami et al. [22] reported that the mycorrhizal plants showed a significant accumulation of non-constitutive hydroxycinnamic acid derivatives, such as the sinapic derivative $\mathrm{I}_{2}$, known to play a crucial role in resistance of date palm to Foa.

Concerning the three modes actions of antagonistic fungi (antibiosis, mycoparasitism and competition), on Foa, there is no study at know confirm this action. The mycoparasitism for example is difficult to demonstrate in situ until very recently due the technical difficulties in making in situ microscopic observation (fluorescence imaging and differential staining)23. Antagonistic fungi species (AFS), can produce antifungal metabolites (Schirmböck et al.,

\section{Volume 6 Issue 12, December 2017}




\section{International Journal of Science and Research (IJSR) \\ ISSN (Online): 2319-7064}

Index Copernicus Value (2016): 79.57 | Impact Factor (2015): 6.391

1994) [24] which may be competitor to fungal pathogens 25,26 , and also promote plant growth [27,28]. In addition, it has been demonstrated that a number of Trichoderma isolates are able to excrete hydrolytic enzymes such as chitinases and $\beta$-1,3-glucanases into the medium when grown in liquid media supplemented with laminarin or chitin29,30. Chitin and $\beta$-1,3-glucans are the main structural components of fungal cell walls[30-32]. It has been suggested that the hydrolases produced by AFS were likely involved in the degradation of fungal cells through alteration of their wall components [30].

In this case, the objectives of this work were to i) determine the inhibition effect by the in vitro test of five antagonistic fungi on mycelial growth and sporulation witch represents the antibiosis action, and ii) determine the mycoparasitism action by detection of accumulation of anti-fungal lytic enzymes and by microscopic observation of destroyed foa's mycelia by these antagonistic fungi species (AFS).

\section{Materials and Methods}

A total of twenty strains of five antagonistic fungal species were tested their efficacy of inhibition on mycelial growth of Foa for detect the antibiosis and mycoparasitism actions. These strains are collected from Saoura region of Algeria in the period September - November 2016. The test of biological control was carried out in our laboratory of phytopathology, in the period September 2016 - February 2017.

Table 1: Foa and antagonistic fungal species strains isolates with their origin

\begin{tabular}{|c|c|c|c|}
\hline $\begin{array}{c}\text { Foa } \\
\text { isolates }\end{array}$ & Origin & Antagonistic fungal species & Strains \\
\hline 1 & Saoura & Aspergillus niger & Ag.n \\
2 & Saoura & Fusarium oxysporum Trichoderma & F.ox \\
3 & Saoura & harzianum & T22 \\
4 & Touat & Trichoderma aureoviride & T.aureo \\
5 & Touat & Trichoderma longibachiatum & T. long \\
6 & Gourrara & \\
7 & Gourrara & & \\
8 & Gourrara & & \\
9 & Mizab & & \\
10 & Mizab & & \\
\hline
\end{tabular}

\subsection{Foa isolates}

Ten Foa isolates (Table 01), originated from Mizab, Saoura, Touat and Gourrara regions (South-West of Algeria). These isolates were grown on PDA medium (potato dextrose agar), at $22{ }^{\circ} \mathrm{c}$ for 5 days.

\subsection{Antagonistic fungi species}

Five antagonistic fungi species (AFS) strains were used for antagonism test, Aspergillus niger, Fusarium oxysporum, Trichoderma harzianum, $T$. aureoviride and $T$. longibachiatum, originated from Western Unity of Research, Algerian National Institute of Agricultural Research (INRAA-URO), Sidi Bel Abbes, Algeria.

\subsection{Antibiosis action test}

Antibiosis action of antagonistic fungi species is represented by the mycelia growth and sporulation inhibitions. Interactions between Foa and AFS were determinate by method of Küçük and Kivanç [33]. This method is based to calculate the growth inhibition rates (GRI\%) of mycelia growth and sporulation of Fao by AFS effect. The inhibition percent was obtained using the formula:

$$
G I R \%=\frac{(R 1-R 2)}{R 2} \times 100
$$

Where GRI\% represents growth inhibition rate, R1 means mycelia growth of Foa and R2 means mycelia growth of control [33].

\subsection{Enzymatic assay (Mycoparasitism action test)}

Antagonistic fungi species (AFS) were cultured at $22{ }^{\circ} \mathrm{C}$ on a synthetic medium containing (grams per litre of distilled water): glucose, 15; MgSO4 7H2O, 0.2; KH2PO4, 0.9; KCl, 0.2; NH4NO3, 1.0; Fe2+, 0.002; and $\mathrm{Zn} 2+, 0.002$. Flasks containing $50 \mathrm{ml}$ of liquid SM were inoculated with $1 \mathrm{ml}$ of a conidial suspension (106 conidia ml-1) of AFS. The glucose in the medium was substituted with one of the following carbon sources (each at $2 \mathrm{mg} \mathrm{ml}-1$ ): laminarin, chitin or Foa cell wall preparation. Cultures were incubated at $28{ }^{\circ} \mathrm{C}$ in a rotary shaker. Supernatants were studied for enzymatic activities33. Foa was inoculated into $250 \mathrm{ml}$ flasks with $50 \mathrm{ml}$ of potato dextrose broth and incubated at $24 \pm 2{ }^{\circ} \mathrm{C}$ for 6 days.

The mycelium was then collected by filtration and thoroughly washed with sterile distilled water and homogenised for $5 \mathrm{~min}$ at the highest speed. The mycelial suspension was centrifuged at $30000 \times \mathrm{g}$ at $4^{\circ} \mathrm{C}$ for $20 \mathrm{~min}$. The pellet was resuspended in distilled water and sonicated on ice 4 times for $5 \mathrm{~min}$ using a sonicator (Sonics \& Materials Inc., USA). The suspension was centrifuged at 800 $\mathrm{x} \mathrm{g}$ at $4{ }^{\circ} \mathrm{C}$ for $10 \mathrm{~min}$ [34]. Chitinase (E.C. 3.2.1.14) activity was determined by following the release of GlcNAc from colloidal chitin. Specific activity was defined as units of enzyme activity per milligram of protein. The activity of $\beta$ 1,3-glucanase [E.C. 3.2.1.39] was determined by following the release of free glucose using the glucose oxidase reagent. Specific activity was expressed as mmol glucose h-1 (mg protein)-1. Protein was determined by the method described by Küçük et al. (2007) [34].

\subsection{Statistical analysis}

All the experiments schemes were randomized complete. At least two replicates per treatment were performed and each whole experiment was repeated independently two times. The collected data were submitted to analysis of variance (ANOVA) by one factor and was performed for the data on antibiosis action was represented by AFS's inhibitions rates of mycelial growth and sporulation. The data on enzymatic activity were subjected to mycoparasitism action of AFS. The F-values were calculated at $p<0.05$. Standard errors has been calculated and marked in tables. The significance of differences among treatments was recorded at $p<0.05$ by the

\section{Volume 6 Issue 12, December 2017}




\section{International Journal of Science and Research (IJSR) \\ ISSN (Online): 2319-7064 \\ Index Copernicus Value (2016): 79.57 | Impact Factor (2015): 6.391}

experimental statement named global randomized with one studied factor (inhibition rates)33,34, and multiple comparisons of the means were conducted according to the Newman-Keuls test at $p<0.0533$. Multiple replicates of the same experiment showing no significant differences were combined within the same analysis unless stated. All data were transformed to ensure the variances homogeneity. Multiple comparisons of the means were conducted according to the Newman-Keuls test at $p<0.0533$. The StatBox software v. 6.4 (Grimmersoft, ed'04, USA) was recorded at $p<0.05$, by the experimental statement named global randomized with one studied factor (inhibition rates) $[33,34]$.

\section{Results}

\subsection{Antibiosis test}

The mycelial growth of Foa was inhibited by all AFS isolates (Fig. 1), with zone inhibition formation. These AFS exhibited an excellent antagonistic activity against mycelia growth of Foa with GIR\% value more than $70 \%$ (Table 2). The isolate T22 was identified as the strongest antagonist against Foa with significantly high of GIR\% value $(80 \%)$. Other four isolates of AFS exhibited GIR\% value between 60 and $75 \%$ (Table 2). The ANOVA indicated significant differences at $1 \%$ level than the control among isolates for inhibition rate (Table 2).

Table 2: Mycelial growth inhibition rates (\%) of Fusarium oxysporum $\mathrm{f}$. sp. albedinis (Foa) on PDA medium in presence of five antagonistic fungi species (AFS) after 7 days of incubation

\begin{tabular}{|c|c|c|c|c|c|}
\hline \multirow[t]{2}{*}{ Foa isolates } & \multicolumn{5}{|c|}{ Growth inhibition rate (GRI) (\%) } \\
\hline & T. harzianum (T22) & T. longibachiatum & T. aureoviride & Aspergillus niger & Fusarium oxysporum \\
\hline 1 & $75 \mathrm{a}$ & $72 \mathrm{a}$ & $72 \mathrm{a}$ & $65 \mathrm{~b}$ & $65 \mathrm{~b}$ \\
\hline 2 & $75 \mathrm{a}$ & $73 \mathrm{a}$ & $71 \mathrm{a}$ & $63 \mathrm{~b}$ & $66 a b$ \\
\hline 3 & $74 a$ & $72 \mathrm{a}$ & $72 \mathrm{a}$ & $64 \mathrm{~b}$ & $66 a b$ \\
\hline 4 & $75 a$ & $71 \mathrm{a}$ & $72 \mathrm{a}$ & $61 \mathrm{c}$ & $65 \mathrm{~b}$ \\
\hline 5 & $75 a$ & $72 \mathrm{a}$ & $73 a$ & $60 \mathrm{c}$ & $64 \mathrm{~b}$ \\
\hline 6 & $75 a$ & $74 \mathrm{a}$ & $72 \mathrm{a}$ & $65 \mathrm{~b}$ & $63 \mathrm{~b}$ \\
\hline 7 & $73 \mathrm{a}$ & $73 a$ & $71 \mathrm{a}$ & $63 \mathrm{~b}$ & $63 \mathrm{~b}$ \\
\hline 8 & $75 a$ & $73 a$ & $72 \mathrm{a}$ & $61 \mathrm{c}$ & $61 \mathrm{c}$ \\
\hline 9 & $75 \mathrm{a}$ & $74 \mathrm{a}$ & $71 \mathrm{a}$ & $62 \mathrm{bc}$ & $62 \mathrm{bc}$ \\
\hline 10 & $72 \mathrm{a}$ & $73 a$ & $73 a$ & $64 \mathrm{~b}$ & $63 \mathrm{~b}$ \\
\hline Foa control & $0 \mathrm{~d}$ & $0 \mathrm{~d}$ & Od & Od & Od \\
\hline \multicolumn{6}{|l|}{ GRI global (\%) } \\
\hline LSD & $5.04 *$ & & & & \\
\hline C. V. $(\%)$ & 22.6 & & & & \\
\hline Sporulation inhibition $(\%)$ & 85 & 82 & 81 & 80 & 80 \\
\hline
\end{tabular}

c.v., Coefficient of variation; a, b, c, d, Ranking of the inhibition rate of mycelial growth is presented in four groups, when the values within a column labelled by the different alphabets are significantly different at $p<0.05$; LSD, Least significant difference at $p<0.05 ; *$, significant effect at $5 \%$ level.
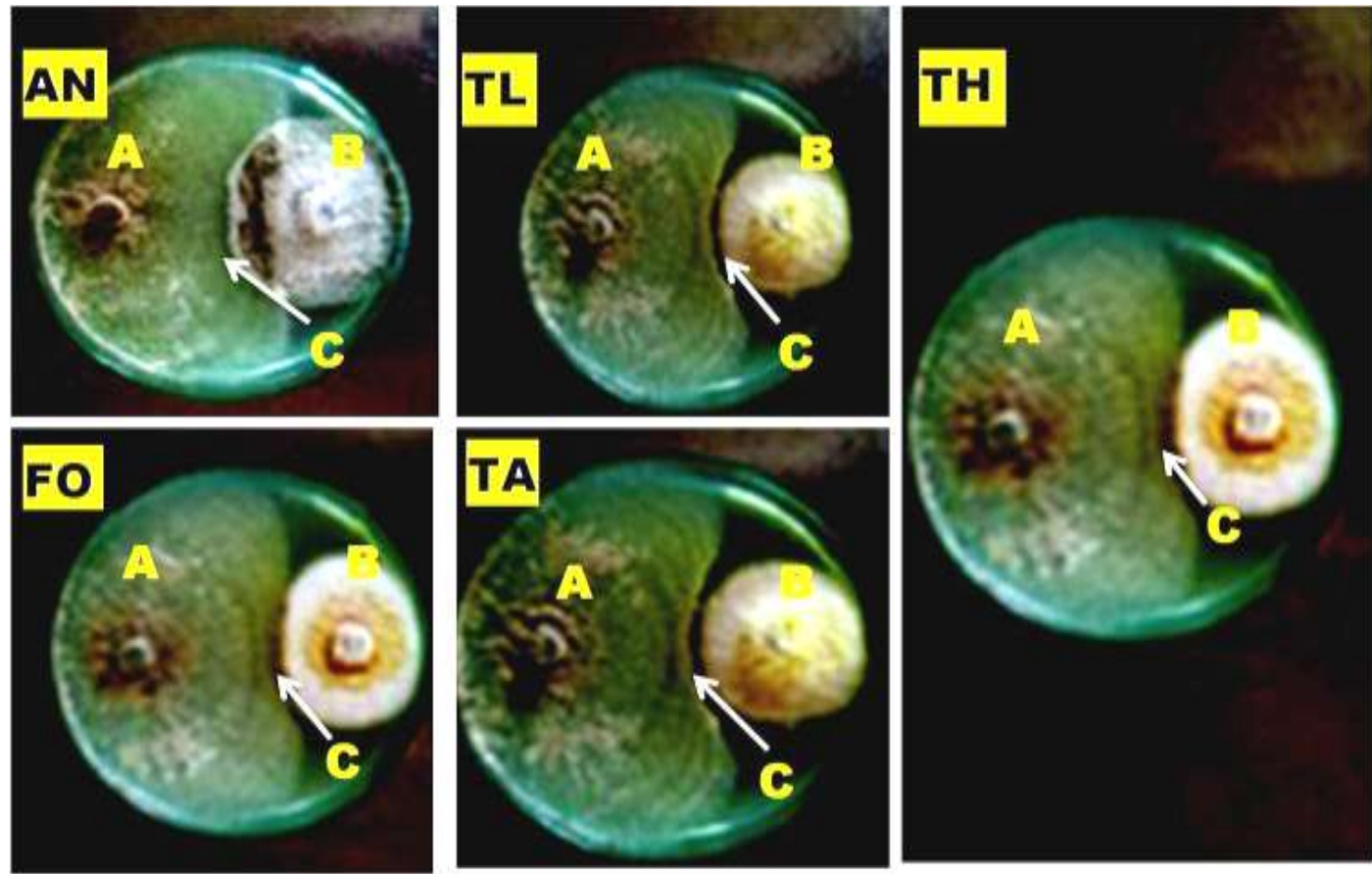

Figure 1: Anatgonistic fungi species effect on mycelial growth of Foa with inhibition zone formation. TH, Foa confrontation with T. harzianum; TA, Foa controntation with T. aureoviride; TL, Foa confrontation with T. longibachiatum; AN, Foa confrontation with Aspergillus niger; FO, Foa confrontation with soil's Fusarium oxysporum. A, Foa colony; B, antagonistic fungi strain colony; $\mathrm{C}$, inhibition zone formation.

Volume 6 Issue 12, December 2017

\section{www.ijsr.net}

Licensed Under Creative Commons Attribution CC BY 


\section{International Journal of Science and Research (IJSR) \\ ISSN (Online): 2319-7064}

Index Copernicus Value (2016): 79.57 | Impact Factor (2015): 6.391

\subsection{Mycoparasitism test}

All tested isolates of AFS showed glucanase and chitinase activity when grown in presence of cell wall constituents of the pathogen. Of the lytic enzymes produced by these isolates, $\beta-1,3$-glucanase activity was much higher than chitinase activity (Table 3 ).

Mycoparasitism action was observed also by microscopic observations of the mycelium harvested in the periphery of Foa colonies on the side of the most effective antagonists revealed generally a coagulation of the fungal cytoplasm, characterized usually by the presence of small vesicles and very often by the appearance of large vacuoles (Fig. 2).
Table 3: Lytic enzymes activity produced by AFS isolates.

\begin{tabular}{|c|c|c|}
\hline AFS strains & $\begin{array}{c}\text { Chitinase } \\
\text { accumulation } \\
(\mu \mathrm{mol} \text { GIcNAc } \mathrm{h}-1 \mathrm{mg} \\
\times \text { protein-1 } \\
(\text { Cell wall of Foa })\end{array}$ & $\begin{array}{c}\text { Glucanase } \\
\text { accumulation } \\
(\mu \mathrm{mol} \mathrm{h}-1 \mathrm{mg} \times \\
\text { protein }-1) \\
(\text { Cell wall of Foa })\end{array}$ \\
\hline Aspergillus niger & 4.07 & 64.02 \\
\hline Fusarium oxysporum & 4.5 & 70.01 \\
\hline Trichoderma harzianum & 8.02 & 100.1 \\
\hline Trichoderma aureoviride & 6.01 & 87.9 \\
\hline Trichoderma & 6.0 & 85.9 \\
\hline longibachiatum & & $2.7^{*}$ \\
\hline ANOVA & $0.4^{*}$ & $2.1^{*}$ \\
\hline LSD isolates 5\% & $0.76^{*}$ & $6.6^{*}$ \\
\hline LSD treatments5\% & & \\
\hline LSD interaction5\% & & \\
\hline Significant at 5\% & & \\
\hline
\end{tabular}

*, Significant at $5 \%$ level.
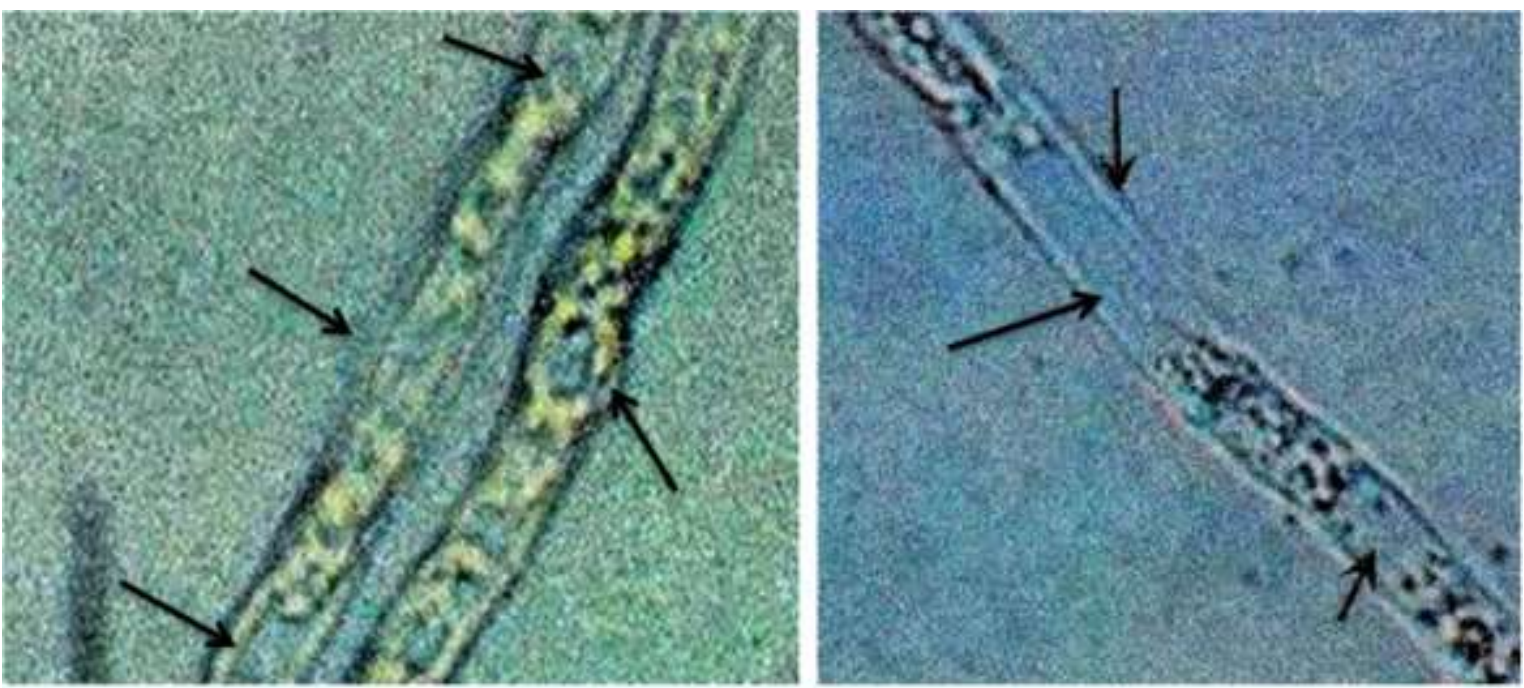

Figure 2: Microscopic observations of Fusarium oxysporum f. sp. albedinis (Foa) mycelia with vacuolization formation by mycelium presence of antagonistic fungi strains

\section{Discussion}

This study was the determination of the AFS efficacy against Foa by the antibiosis and mycoparasitism actions. The impact of the intensive use of chemical pesticides on the environment has resulted in the increased interest in biocontrol strategies for plant disease management[35-40]. The biological control importance based antibiosis and mycoparasitism actions has not been documented widely8, all works of biological control on induction of plant resistance, phenolic compounds and antagonistic bacteria[10-12, 29, 41, 42]. In this work, it was tested five antagonistic fungi species (AFS) strains, for their potential to control Bayoud in date palm, a disease caused by Foa.

Hydrolytic enzymes, such as chitinase and glucanase are thought to be closely related to the mycoparasitism [26,43,44,45].

The potential of AFS as biological agents of plant pathogens was first recognized against soil-borne root pathogens like Rhizoctonia solani, Pythiul ultimum, Fusarium oxysporum, Fusarium solani, Sclerotium rolfsii and Cochliobolus sativus $[46,47]$.

The in vitro antibiosis tests on mycelia growth and sporulation have shown that simultaneous co-culture of these microorganisms and Foa does not stop completely its growth. This inhibition effect of Foa might be the result of antifungal compounds released by the antagonists into the culture media. In some cases of interaction with Foa antagonists, the sporulation of Foa colonies was highly reduced particularly in the border where the inhibition is stirring8, 12 .

The mycoparasitism potential of AFS wasn't well documented23. Hydrolytic enzymes, such as chitinase and glucanase are thought to be closely related to the mycoparasitism $26,43,44,45$. The secretion of hydrolytic enzymes, such as chitinase and glucanase are thought to be closely related to the mycoparasitism $26,43,44,45,48$. All tested isolates showed glucanase and chitinase activity when grown in presence of cell wall constituents of the pathogen (Table 2). Of the lytic enzymes produced by antagonistic fungi isolates, $\beta$-1,3-glucanase activity was much higher than chitinase activity (Table 2). Similar variations in different isolates have been observed for various lytic enzymes in Trichoderma32,49,50,51. This result is similar to that by reported Innocenti et al. (2003) 30, in which antagonist microorganism produced high levels of enzymes when grow on Rhizoctonia cerealis mycelia, and by Kuçuk et al. (2007)34 on Ascochyta rabiei, causal agent of ascochyta blight on chickpea (Cicer arietinum L.).

\section{Volume 6 Issue 12, December 2017}




\section{International Journal of Science and Research (IJSR) \\ ISSN (Online): 2319-7064}

Index Copernicus Value (2016): 79.57 | Impact Factor (2015): 6.391

Further studies are conducted in order to highlight the in planta effect of these antagonists on the endophytic development of Foa, and to set up the ecological conditions required for their settlement within the date palm rhizosphere.

\section{Conclusion}

We showed in this study the presence of lytic enzymes chitinase and $\beta$-1,3-glucanase secreted by AFS for mycelia alteration of Foa and inhibition of growth by antifungal compounds inhibitors. In this study we have investigated the selection of a set of antagonistic fungi species that can act as antagonists against Foa based on their ability to inhibit more or less strongly its mycelial growth and/or sporulation, by antibiosis and mycoparasitism actions. In Algeria, the biological control against bayoud disease should provide a potential effective approach for the prevention of healthy groves (South-East of Algerian desert), and increase the levels of these AFS and their specific activities could be a selective advantage in antagonism and which is able to control the bayoud of date palm in oases is being evaluated.

\section{References}

[1] Fernandez, D., M. Lourd, M. Ouinten, A. Tantaoui and J.P. Geiger, 1995. Le Bayoud du palmier dattier, une maladie qui menace la phoeniciculture. Phytoma, 469: 36-39.

[2] El-Modafar, C., 2010. Mechanisms of date palm resistance to Bayoud disease: current state of knowledge and research prospects. Physiol. Mol. Plant. Pathol., 74: 287-294.

[3] Benzohra, I. E., M. Megateli, B.A. Elayachi, M. Zekraoui, K. Djillali, A. Bouafia, S. Benouis, A. Benaziza and A. Rekis, 2017. Integrated management of Bayoud disease on date palm (Phoenix dactylifera L.) caused by Fusarium oxysporum f. sp. albedinis in Algeria. Journal Algérien des Régions Arides, 14: 93100.

[4] Benzohra, I.E., M. Megateli and R. Berdja, 2015. Bayoud disease of date palm: History, epidemiology and integrated disease management. African Journal of Biotechnology, 14(7): 542-550. doi 10.5897/AJBX2014.14292.

[5] Djerbi, M. 1990. Methodes de diagnostic du Bayoud du palmier dattier. Bull. ' OEPP/EPPO Bull., 20: 607-613.

[6] Louvet, J. 1991. Que devons-nous faire pour lutter contre le Bayoud? Physiologie des arbres et Arbustes en zones arides et semi arides: Groupes d'Etudes d'Arbre, Paris-France, pp. 337-346.

[7] ElHadrami, A., D. Kone and P. Lepoivre, 2005. Effect of juglone on active oxygenspecies and antioxidants in susceptible and partial resistant banana cultivars to Black Leaf Streak Disease. European Journal of Plant Pathology, 113: 241-254.

[8] El Hassni, M., A. El Hadrami, F. Daayf, M. Cherif, E. Ait Barka and I. El Hadrami, 2007. Biological control of bayoud disease in date palm: Selection of microorganisms inhibiting the causal agent and inducing defense reactions. Envir. Exp. Bot., 59: 224234.
[9] Arfaoui, A., A. El Hadrami, Y. Mabrouk, B. Sifi, A. Boudabous, I. El Hadrami, F. Daayf and M. Cherif, 2007. Treatment of chickpea with Rhizobium isolates enhances the expression of phenylpropanoid defenserelated genes in response to infection by Fusarium oxysporum f. sp. ciceris. Plant Physiol. Biochem., 45: 470-479.

[10] El Hassni, M., A. El Hadrami, F. Daayf, E. Ait Barka and A. El Hadrami, 2004a. Introduction Bayoud disease, a vascular disease of date palm (Phoenix dactylifera L.) is caused by a telluric fungus Fusarium oxysporum f. sp. albedinis (Foa). Phytopathologia Mediterranea, 43: 195-204.

[11]El Hassni, M., F. Jaiti, A. Dihazi, E. Ait Barka, F. Daayf, and I. El Hadrami, 2004b. Enhancement of defense responses against Bayoud disease by treatment of date palm seedlings with an hypoaggressive Fusarium oxysporum isolate. Journal of Phytopathology, 152: 182-189.

[12] Dihazi, A., F. Jaiti, W. Taktak, O. Kelani-Feki, S Jaoua, A. Driouich, M. Baaziz, F. Daayf and M.A. Serghini, 2012. Use of two bacteria for biological control of bayoud disease caused by Fusarium oxysporum in date palm (Phoenix dactylifera L.) seedlings. Plant Physiology and Biochemistry, 55: 7-15.

[13] Thomashow, S.L., 1996. Biological control of plant root pathogens. Curr. Opin. Biotechnol., 7 : 343-347.

[14] Benhamou N., C. Garand and A. Goulet, 2002. Ability of nonpathogenic Fusarium oxysporum strain F047 to induce resistance against Pythium ultimum infection in cucumber. Appl. Environ. Microbiol., 68: 4044-4060.

[15] Glick, B.R. and Y. Bashan, 1997. Genetic manipulation of plant growth-promoting bacteria to enhance biocontrol of phytopathogens. Biotechnology Advences, 15(2): 353-378.

[16] Van Loon, L.C., P.A.H.M. Bakker and C.M.J. Pieterse, 1998. Systemic resistance induced by rhizosphere bacteria. Annual Review of Phytopathology, 36: 453483.

[17] Chérif M., N. Sadfi, N. Benhamou, A. Boudabbous, A. Boubaker, M.R. Hajlaoui and Y. Tirilly, 2002. Ultrastructure and cytochemistry of in vitro interactions of the antagonistic bacteria Bacillus cereus X16 and B. thuringiensis 55T with Fusarium roseum var. sambucinum. Journal of Plant Patholology, 84: 83-93.

[18] Getha, K. and S. Vikineswary, 2002. Antagonistic effects of Streptomyces violaceusniger strain G10 on Fusarium oxysporum f. sp. cubense race 4: indirect evidence for the role of antibiosis in the antagonistic process. J. Ind. Microbiol. Biotechnol., 28: 303-310.

[19] Larkin, R.P. and D.R. Fravel, 2002. Effects of varying environmental conditions on biological control of Fusarium wilt of tomato by nonpathogenic Fusarium spp. Phytopathology, 92: 1160-1166.

[20] Hammerschmidt, R. and J. Kuc, 1995. Induced Resistance to Disease in Plants, Kluwer Academic Publishers, Dordsecht. pp. 182.

[21] Jaiti, F., A. Meddich, M. Kassami and I. El Hadrami, 2008. Effect of Arbuscular Mycorrhization on the accumulation of hydroxycinnamic acid derivatives in date palm seedlings challenged with Fusarium oxysporum f. sp. albedinis. Journal of Phytopathology, 156: 641-646. 


\section{International Journal of Science and Research (IJSR) \\ ISSN (Online): 2319-7064}

Index Copernicus Value (2016): 79.57 | Impact Factor (2015): 6.391

[22] El-Hadrami, I., T. Ramos, M. El Bellaj, A. El-IdrissiTourane and J.J. Macheix, 1997. A sinapic derivative as induced defense compound of date palm against Fusarium oxysporum f. sp. albedinis, the agent causing Bayoud disease. Journal of Phytopathology, 145: 329333.

[23] Verma, M., S.K. Brar, R.D. Tyagi, R.Y. Surampalli and J.R. Valéro, 2007. Anatgonistic fungi Trichoderma spp. : Panoply of biological control. Biochemical Engineering Journal, 37: 01-20.

[24] Schirmböck, M., M. Lorito, Y.L. Wang, C.K. Hayes, I. Arisan-Atac, F. Scala, G.E. Harman and C.P. Kubicak, 1994. Parallel formation and synergisim of hydrolytic enzymes and peptaibol antibiotics, molecular mechanisms involved in the antagonistic action of Trichoderma harzianum against phytopathogenic fungi. Appl. Environ. Microbiol., 34: 860-864.

[25]Bae, Y.S. and G.R. Knudsen, 2005. Soil microbial biomass influence growth and biocontrol efficacy of Trichoderma harzianum. Biol. Control, 32: 236-242. Brewer M.T., Larkin R.P. (2005). Efficacy of several potential biocontrol organisms against Rhizoctonia solani on potato. Crop Protection, 24: 939-950.

[26] Brewer, M.T. and R.P. Larkin, 2005. Efficacy of several potential biocontrol organisms against Rhizoctonia solani on potato. Crop Protection, 24 (11): 939-950.

[27] Windham, M.T., Y. Elad and R. Baker, 1996. A mechanisms for increased plant growth induced by Trichoderma spp. Phytopathology, 76: 518-521.

[28] Inbar, J., M. Abramsky, D. Cohen and I. Chet, 1994. Plant growth enhancement and disease control by Trichoderma harzianum in vegetable seedling grown under commercial conditions. Euro. J. Plant Pathol., 100: 337-346.

[29] Elad, Y. 2000. Biological control of foliar pathogens by means of Trichoderma harzianum and potential modes of action. Crop Protection, 19: 709-714.

[30] Innocenti, G., R. Roberti, M. Montanari and E. Zakrisson, 2003. Efficacy of microorganisms antagonistic to Rhizoctonia cerealis and their cell wall degrading enzymatic activities. Mycological Research, 107(4): 421-427.

[31]Cherif M. and N. Benhamou, 1990. Cytochemical aspects of chitin breakdown during the parasitic action of Trichoderma sp. on Fusarium oxysporum f. sp. radicis-lycopersici. Phytopathology, 80: 1406-1412.

[32] Soglio, F.K., B.L. Bertagnolli, J.B. Sinclair, G.Y. Yu, and D.M. Eastburn, 1998. Production of chitinolytic enzymes and endoglucanase in the soybean rhizosphere in the presence of Trichoderma harzianum and Rhizoctonia solani. Biological Control, 12: 111-117.

[33] Küçük, Ç. and M. Kivanç, 2003. Isolation of Trichoderma spp. and their antifungal, biochemical and physiological features. Turk. J. Biol., 27: 247-253.

[34] Kuçuk, Ç., M. Kivanç, E. Kinaci and G. Kinaci, 2007. Efficacy of Trichoderma harzianum (Rifaii) on inhibition of ascochyta blight disease of chickpea. Annals of Microbiology, 57: 665-668.

[35] Benhamou, N., J.W. Kloepper, A. Quadt-Hallman and S. Tuzun, 1999. Induction of Defense-Related Ultrastructural Modifications in Pea Root Tissues Inoculated with Endophytic Bacteria. Plant Physiology, 112 (3): 919-929.
[36] Kumar, S., M. Thakur and A. Rani, 2014. Trichoderma: Mass production, formulation, quality control, delivery and its scope in commercialization in India for the management of plant diseases. African Journal of Agricultural Research, 9(53): 3838-3852.

[37]El Hadrami, A., L.R. Adam and F. Daayf, 2011. Biocontrol treatments confer protection against Verticillium dahliae infection of potato by inducing anti-microbial metabolites. Mol. Plant Micr. Interact, 24: 328-335.

[38]Elad Y., I. Chet and Y. Henis, 1982. Degradation of plant pathogenic fungi by Trichoderma harzianum. Can. J. Microbiol., 28: 719-725.

[39] Souna, F., I. Himri, R. Benabbas, F. Fethi, C. Chaib, M. Bouakka and A. Hakko, 2012. Evaluation of Trichoderma harzianum as a biocontrol agent against vascular fusariosis of date palm (Phoenix dactylifera L.). Journal of Basic and Applied Sciences, 6(5): 105114.

[40] Ng, L.C., A. Ngadin, M. Azhari and N.A. Zahari, 2015. Potential of Trichoderma spp. as biological control agents against Bakanae pathogen (Fusarium fujikuroi) in rice. Asian Journal of Plant Pathology, 9(2): 46-58.

[41]Rajput, A.Q. and S. Shahzad, 2015. Growth and sporulation of Trichoderma polysporum on organic substrates by additions of carbon and nitrogen sources. Pakistan Journal of Botany, 47 (3): 979-986.

[42] Nicholson, R.L. and R. Hammerschmidt, 1992. Phenolic Compounds and Their Role in Disease Resistance. Annual Review of Phytopathology, 30: 369389.

[43] Daayf, F., M. El Bellaj, M. El Hassni, F. Jaiti and I. ElHadrami, 2003. Elicitation of soluble phenolics in date palm (Phoenix dactylifera L.) callus by Fusarium oxysporum f. sp. albedinis culture medium. Environ. Exp. Bot., 49: 41-47.

[44] Chet, I. 1990. Biological control of soil-borne plant pathogens with fungal antagonists in combination with soil treatments. In: D. Hornby, Ed., Biological Control of Soil-borne Plant Pathogens, CAB InternationaLs, Wallingford, pp. 15-25.

[45] Harman, G.E., C.R. Howell, A. Viterbo, I. Chet and M. Lorito, 2004. Trichoderma species-opportunistic, avirulent plant symbionts. Nature Rev. 02: 43-56.

[46] Donzelli, B.G.G., K.J. Siebert and G.E. Harman, 2006. Response surface modeling of factors influencing the production of chitinolytic and $\beta$-1,3-glucanolytic enzymes in Trichoderma atroviride strain P1. Enzyme Microb. Technol., 12: 12-20.

[47] Biles, C.L. and J.P. Hill, 1988. Effect of Trichoderma harzianum on sporulation of Cochliobolus sativus on excised wheat seedling leaves. Phytopathology, 78: 656-659.

[48] Howell, C. R. 2003. Mechanisms employed by Trichoderma species in the biological control of plant diseases : the history and evolution of current concepts. Plant Disease, 87: 04-10.

[49]Zaim, S., L. Belabid and M. Belahcene, 2013. Biocontrol of chickpea Fusarium wilt by Bacillus spp. Rhizobacteria. Journal of Plant Protection Research, 53 (2): 177-183. 


\section{International Journal of Science and Research (IJSR)}

ISSN (Online): 2319-7064

Index Copernicus Value (2016): 79.57 | Impact Factor (2015): 6.391

[50] Sivan, A. and I. Chet, 1989. Degradation of fungal cell walls by lytic enzymes of Trichoderma harzianum. J. Gen. Microbiol., 135: 675-682.

[51]Hibar, K., M. Daami-Remadi and M. El-Mahdjoub, 2007. Effets de certains fongicides de synthèse et biologiques sur la croissance mycélienne et l'agressivité de Fusarium oxysporum f. sp. radicis-lycopersici. Tropicultura, 25: 146-152.

Volume 6 Issue 12, December 2017

www.ijsr.net

Licensed Under Creative Commons Attribution CC BY 